\title{
Impact of the Sidhmukh canal irrigation project (SCIP) on landscape modification and agriculture at Bhadra tehsil segment, District Hanumangarh, Rajasthan
}

\author{
Bainda, S.K. ${ }^{1}$, Malhotra, G.S. ${ }^{2} \bowtie$
}

Received: 28.12 .2020

Revised: 27.02 .2021

Accepted: 05.04.2021

\begin{abstract}
The study was conducted to know the landscape modification and agricultural intensification at a terrestrial segment of the Sidhmukh Canal Irrigation Project (SCIP) command area. The study confirms that the inception of the Sidhmukh Canal Project caused a massive land-use pattern change and shifted irrigation systems towards rain-fed farming to canal irrigation. Furthermore, the increased water availability by SCIP has extensively inflated irrigated land area, changed cropping pattern and land productivity. The study noticed a significant positive impact of SCIP on agricultural intensification. The study was accomplished by analysing primary data provided by the Department of Water Resources, Department of Agriculture, and Department of Economics \& Statistics, Rajasthan Government.
\end{abstract}

Key words: Sidhmukh canal irrigation project, Inland drainage project, Nohar

\section{Introduction}

Agriculture is the most critical component of the Indian Economy. It represents $18 \%$ of the Indian GDP and provides employment and livelihood to half of the nation's workforce (Hakkim et al., 2016). Although India is the largest producer of pulses, rice, wheat, sugarcane, cotton, and jute, agricultural land productivity is still significantly low compared to major developed countries (Kala, 2017). Ecological studies have confirmed that land productivity is limited by several factors but mainly by water availability and soil nutrients (Mueller et al., 2010). Unfortunately, in India, water resources and water availability is not being managed wisely. From an agricultural point of view, several large terrains of the country, especially in Rajasthan state, are still not well connected by the continued water source (Ghosh, 2011). For efficient water management and to support agriculture, the Indian government has started several water projects in the different areas of the nation (Kumar \& Rai, 1993). Among them, Sidhmukh Canal Irrigation Project (SCIP) is a known successful project that drastically changed the land use pattern or rather

\section{Author's Address}

${ }^{1}$ Om Sterling Global University, Hisar, Haryana, India.

${ }^{2}$ Mody University of Science and Technology, Laxmangarh, Rajasthan, India.

E-mail.: gurmeet.malhotra@gmail.com converted desertic land into fertile agricultural land, changed cropping pattern and increased land productivity. The SCIP was started in 1989 to use the Ravi-Beas Rivers water in the north-eastern part of Rajasthan. Besides the drinking water supply to the region, it proposed to provide perennial irrigation primarily to the un-irrigated desert land of Nohar and Bhadra tehsils in Hanumangarh district and some land in Rajgarh and Taranagar tehsils of Churu district, Rajasthan (Kavdia, 1993; Schrevel, 1997). The present study considered a terrestrial segment of the command area of SCIP that comes under the Bhadra tehsil, Hanumangarh district, Rajasthan, and attempts were made to explore the landscape modification and agricultural intensification. However, the entire region has been converted swiftly from desert/barren land to fertile land by the SCIP and other irrigation projects, and it has vast ecological implications to understand the landscape modification.

\section{Materials and Methods}

The primary data were gathered by reviewing the published reports, official documents and maps of the Department of Water Resources, Department of Agriculture, and Department of Economics \& Statistics, Rajasthan Government (GOR, 2019). In addition, the data related to irrigated command 
area, crop patterns and land productivity were referred from the "Rajasthan Agriculture Statistics" and "Rajasthan Economic Review" of respective years. Further, data were statistically analysed to perceive the outcomes.

\section{Study Area}

The study is focused on a terrestrial segment of the inland drainage project, namely the Sidhmukh Canal Irrigation Project (SCIP). This terrestrial segment is a command area of the SCIP and comes under the Bhadra Tehsil of Hunumangarh district, Rajasthan (Figure-1). Originally, this terrestrial segment was a desertic terrain and contained scattered patches of rain-fed farming. The natural vegetation and crops grown in the landscape were arid and semi-arid type. The emergence of the SCIP caused a massive change in the terrain, and accordingly, it also altered the components of the agroecosystems at a significant level.

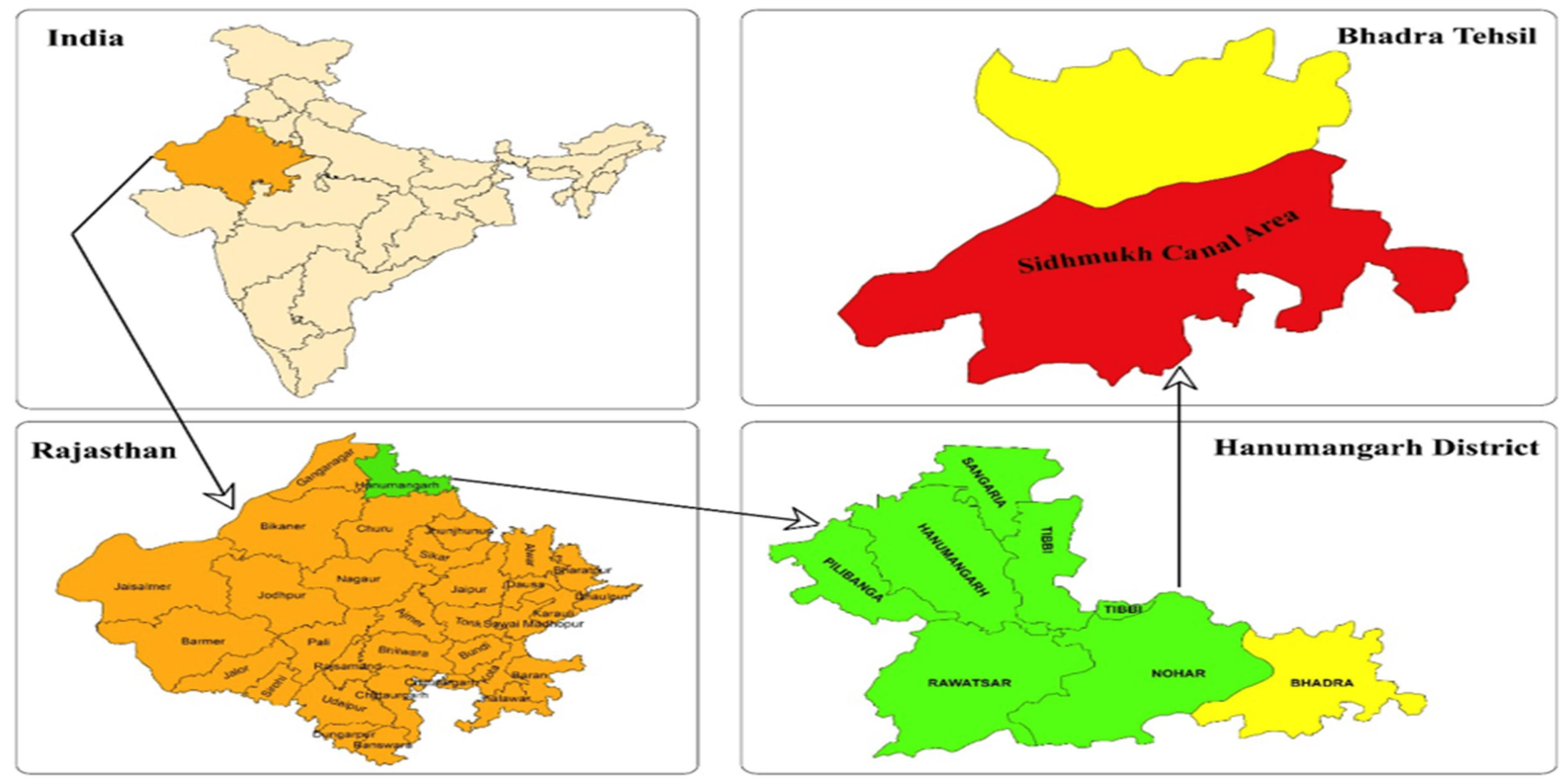

Figure 1: Location map of the study area.

\section{Results and Discussion}

The SCIP is playing a vital role in the agriculture of the region. It is bringing sustainable water availability to its command area. The analysis of the collected data has identified changes and their effects on the agricultural systems of the region.

\section{Landscape Modification}

The study area covers 81,092 hectares of irrigated land, which was transferred by the many SCIP command area development phases since 2002. The collected data reveals that in 2002, the actual area of irrigated land was only 17,143 hectares, and the attained target of project fulfilment was $21.14 \%$ (Table-1). Further execution of command area development, in 2004 the actual area attained under SCIP was enhanced up to 18,216 hectares (22.46\%), consequently 25,067 hectares $(30.91 \%)$ in $2006,32,266$ hectares $(39.79 \%)$ in $2008,51,633$ hectares $(63.67 \%)$ in 2010, 59,450 hectares $(73.31 \%)$ in $2012,71,831$ hectares $(88.58 \%)$ in $2014,78,828$ hectares $(97.21 \%)$ in 2016 and 81,092 hectares (100\%) in 2018 (Table-1, Figure-2).

Irrigation is crucial for enhancing farming and converting infertile barren land to fertile agricultural land (Clemmens \& Molden, 2007). The temporal landscape modification and project accomplishment rate of SCIP indicate that the study area is attaining an increased area of irrigated land. Thus, the inland drainage project (SCIP) is succeeding in order to convert the barren and rainfed agricultural land to canal irrigated fertile land and justifying its proposed objectives and benefiting the region for agricultural prosperity.

\section{Modification in Cropping Pattern}

The collected data reveals that before the command area development of the SCIP, Bajra, Gwar, Gram, 
Impact of the Sidhmukh canal irrigation project (SCIP) on landscape

Table 1: Temporal landscape modification and project accomplishment rate of SCIP.

\begin{tabular}{|c|c|c|c|c|}
\hline Year & $\begin{array}{c}\text { Total Projected Area } \\
\text { under Sidhmukh Canal } \\
\text { Project (In Hectare) }\end{array}$ & $\begin{array}{c}\text { Actual Irrigated Area under } \\
\text { Sidhmukh Canal Project } \\
\text { (In Hectare) }\end{array}$ & $\begin{array}{c}\text { Non-irrigated Area } \\
\text { (In Hectare) }\end{array}$ & $\begin{array}{c}\text { \% of Project } \\
\text { accomplishment }\end{array}$ \\
\hline $\mathbf{2 0 0 2}$ & 81092 & 17143 & 63949 & 21.14 \\
\hline $\mathbf{2 0 0 4}$ & 81092 & 18216 & 62876 & 22.46 \\
\hline $\mathbf{2 0 0 6}$ & 81092 & 25067 & 56025 & 30.91 \\
\hline $\mathbf{2 0 0 8}$ & 81092 & 32266 & 48826 & 39.79 \\
\hline $\mathbf{2 0 1 0}$ & 81092 & 51633 & 29459 & 63.67 \\
\hline $\mathbf{2 0 1 2}$ & 81092 & 59450 & 21642 & 73.31 \\
\hline $\mathbf{2 0 1 4}$ & 81092 & 71831 & 9261 & 88.58 \\
\hline $\mathbf{2 0 1 6}$ & 81092 & 78828 & 2264 & 97.21 \\
\hline $\mathbf{2 0 1 8}$ & 81092 & 81092 & 0 & 100.00 \\
\hline
\end{tabular}

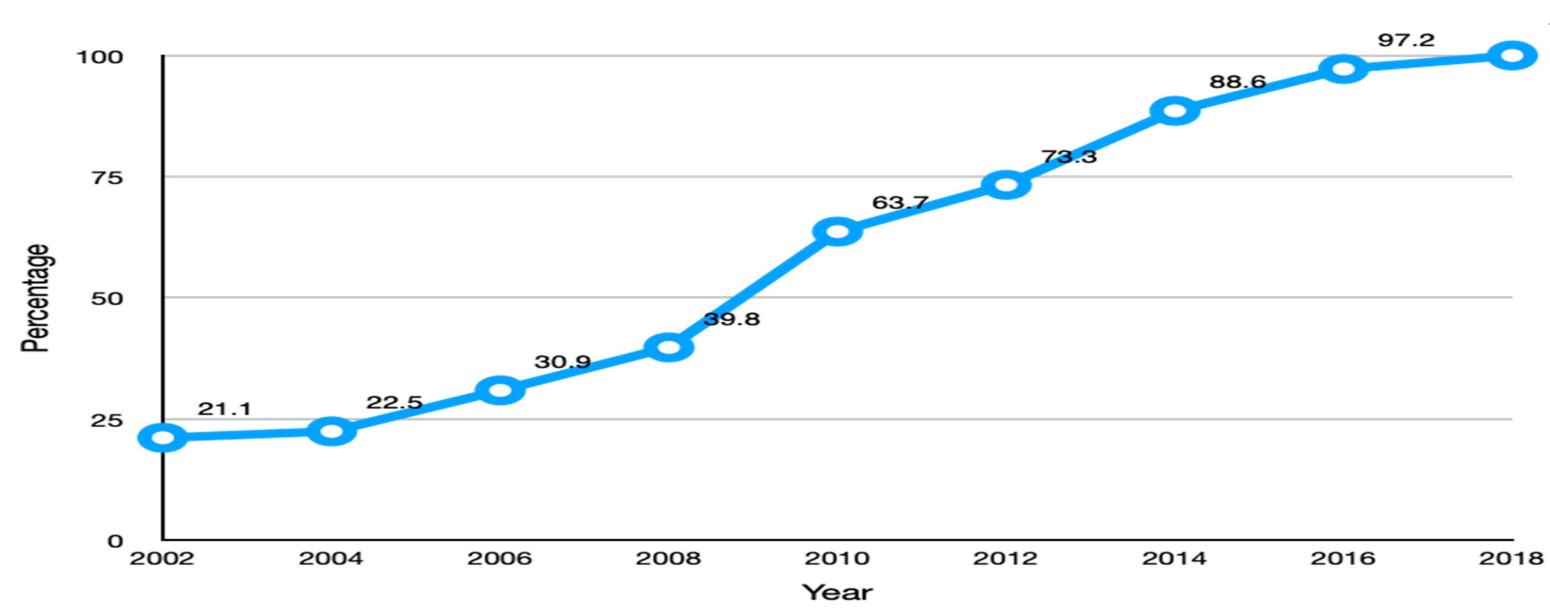

Figure 2: SCIP accomplishment rate between 2002-2018

Mustard, Moong, and Taramira were major crops hectares), Gram (7,728 hectares), Mustard (6,072 and only grown by rainfed farming systems. hectares), Moong (3,312 hectares), and Taramira However, a larger area, 63,949 hectares were under (2,208 hectares) (Table-2, Figure-3 \& 4).

rainfed farming systems. Therefore, assuredly, Likewise, in successive years, the area under canal agricultural productivity was also significantly low irrigation stretched, rain-fed farming land declined, with rainfed farming systems (Rockström et al., and land coverage for the same crops altered. 2003).

Besides, the cropping pattern also turned from In 2002, according to land coverage, Bajra was a Bajra, Gwar and Taramira to Wheat, Cotton, and commonly grown crop $(28,287$ hectares), Groundnut, in the influence of canal irrigation. afterwards Gwar (7,715 hectares), Gram (6,172 Accordingly, from 2002-2018, a steep downfall hectares), Mustard (4,114 hectares), Moong (3,086 was recorded in the land coverage of Bajra (28,287 hectares), and Taramira (2,057 hectares). Yet, the noticeable thing is that the larger portions of all crops were under rainfed farming systems, as only 17,143 hectares of land were under the SCIP in 2002 (Table-2, Figure-3 \& 4).

In 2004, owing to the command area development of SCIP, the area under canal irrigation got increased, and land coverage for the same crops altered as Bajra (27,600 hectares), Gwar (8,280

to 2,572 hectares), a significant decline in Moong (3,086 to 1,717 hectares), a rise and fall in Gwar (7,715 to 4,292 hectares), and a systematic sweep in Taramira $(2,057$ hectares to nil). On the other side, the inception and rise of Ground Nut $(0-5,150$ hectares), Wheat (0-29,182 hectares) and Cotton (024,032 hectares), and the systematic rise in Mustard (4,114-10,300 hectares) and Gram (6,172-8,583 hectares) were recorded (Table-2, Figure- $3 \& 4$ ). 
Bainda and Malhotra

Table 2: Overall change in cropping pattern of study area between 2002-2018

\begin{tabular}{|c|c|c|c|c|c|c|c|c|c|c|}
\hline S.N. & Crop & $\mathbf{2 0 0 2}$ & $\mathbf{2 0 0 4}$ & $\mathbf{2 0 0 6}$ & $\mathbf{2 0 0 8}$ & $\mathbf{2 0 1 0}$ & $\mathbf{2 0 1 2}$ & $\mathbf{2 0 1 4}$ & $\mathbf{2 0 1 6}$ & $\mathbf{2 0 1 8}$ \\
\hline $\mathbf{1}$ & Bajra & 28287 & 27600 & 25679 & 23527 & 15593 & 16695 & 7581 & 2572 & 2575 \\
\hline $\mathbf{2}$ & Gwar & 7715 & 8280 & 9782 & 10083 & 9653 & 10335 & 5896 & 4286 & 4292 \\
\hline $\mathbf{3}$ & Gram & 6172 & 7728 & 9171 & 10083 & 11138 & 11925 & 10950 & 8572 & 8583 \\
\hline $\mathbf{4}$ & Mustard & 4114 & 6072 & 10394 & 15461 & 14850 & 15900 & 10108 & 10286 & 10300 \\
\hline $\mathbf{5}$ & Moong & 3086 & 3312 & 4891 & 4705 & 5198 & 5565 & 1685 & 1714 & 1717 \\
\hline $\mathbf{6}$ & Taramira & 2057 & 2208 & 1223 & 1344 & 1485 & 1590 & 0 & 0 & 0 \\
\hline $\mathbf{7}$ & Ground Nut & 0 & 0 & 0 & 2017 & 2970 & 3180 & 4212 & 5143 & 5150 \\
\hline $\mathbf{8}$ & Wheat & 0 & 0 & 0 & 0 & 8168 & 8745 & 24427 & 30002 & 29182 \\
\hline $\mathbf{9}$ & Cotton & 0 & 0 & 0 & 0 & 5198 & 5565 & 19373 & 23144 & 24032 \\
\hline
\end{tabular}

Table 3: Land productivity for different crops in study area

\begin{tabular}{|c|c|c|c|c|c|c|}
\hline & \multicolumn{7}{|c|}{ (in Quintal/bigha) } \\
\hline Crop & 2008 & 2010 & 2012 & 2014 & 2016 & 2018 \\
\hline Wheat & 4.50 & 4.50 & 5.50 & 6.25 & 6.50 & 7.00 \\
\hline Mustard & 4.25 & 5.00 & 5.50 & 5.50 & 5.75 & 6.00 \\
\hline Gram & 2.75 & 3.25 & 4.00 & 4.25 & 4.50 & 4.50 \\
\hline Cotton & 5.00 & 5.00 & 5.75 & 6.00 & 6.50 & 7.25 \\
\hline Gwar & 4.25 & 4.25 & 4.75 & 5.25 & 5.75 & 6.00 \\
\hline Bajra & 4.00 & 4.00 & 4.25 & 4.25 & 4.50 & 4.50 \\
\hline Moong & 4.25 & 4.25 & 5.00 & 6.25 & 7.00 & 7.25 \\
\hline
\end{tabular}

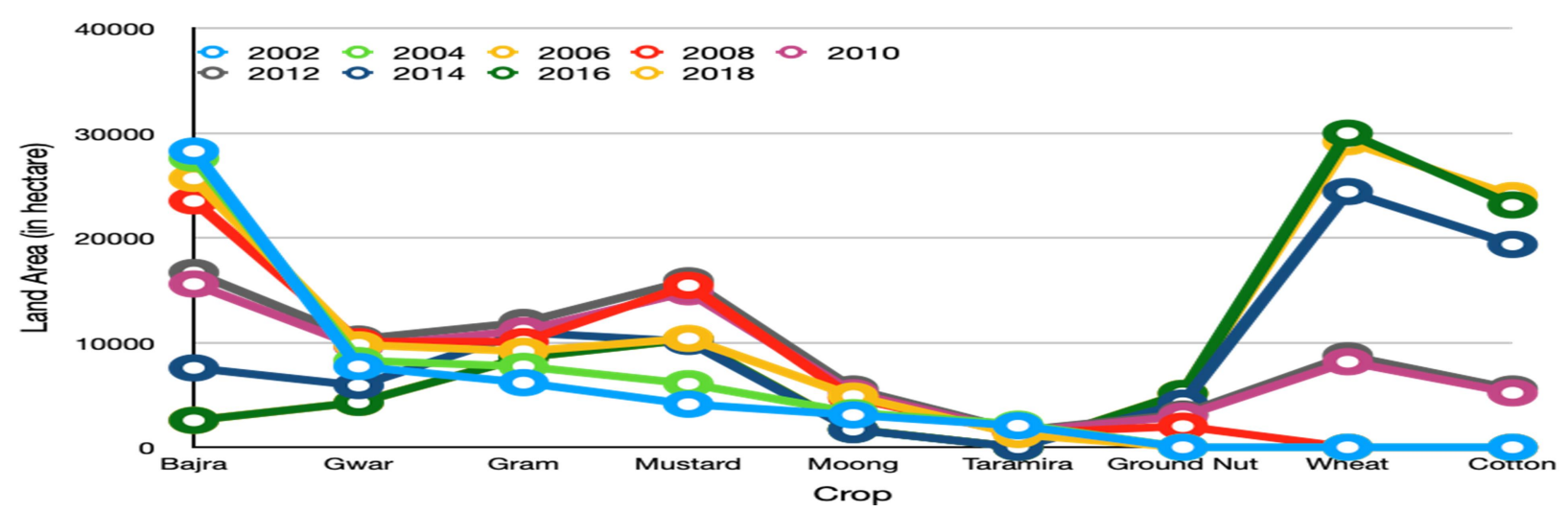

Figure 3: Overall change in cropping pattern of study area between 2002-2018 (year-wise)

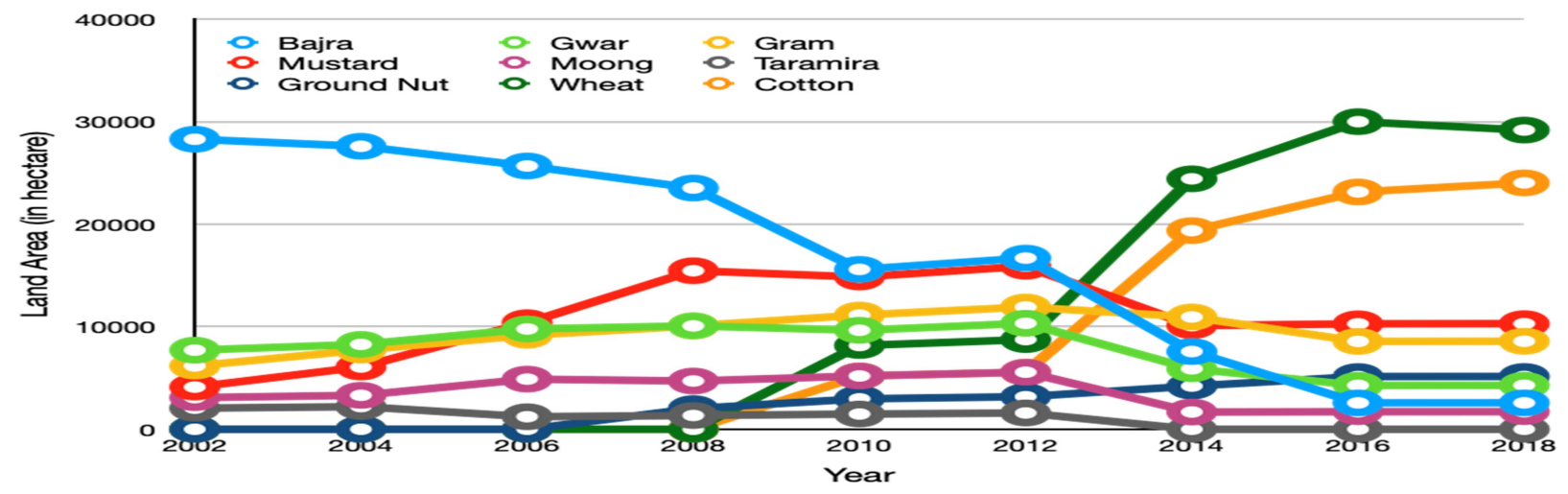

Figure 4: Overall change in cropping pattern of study area between 2002-2018 (crop-wise) 


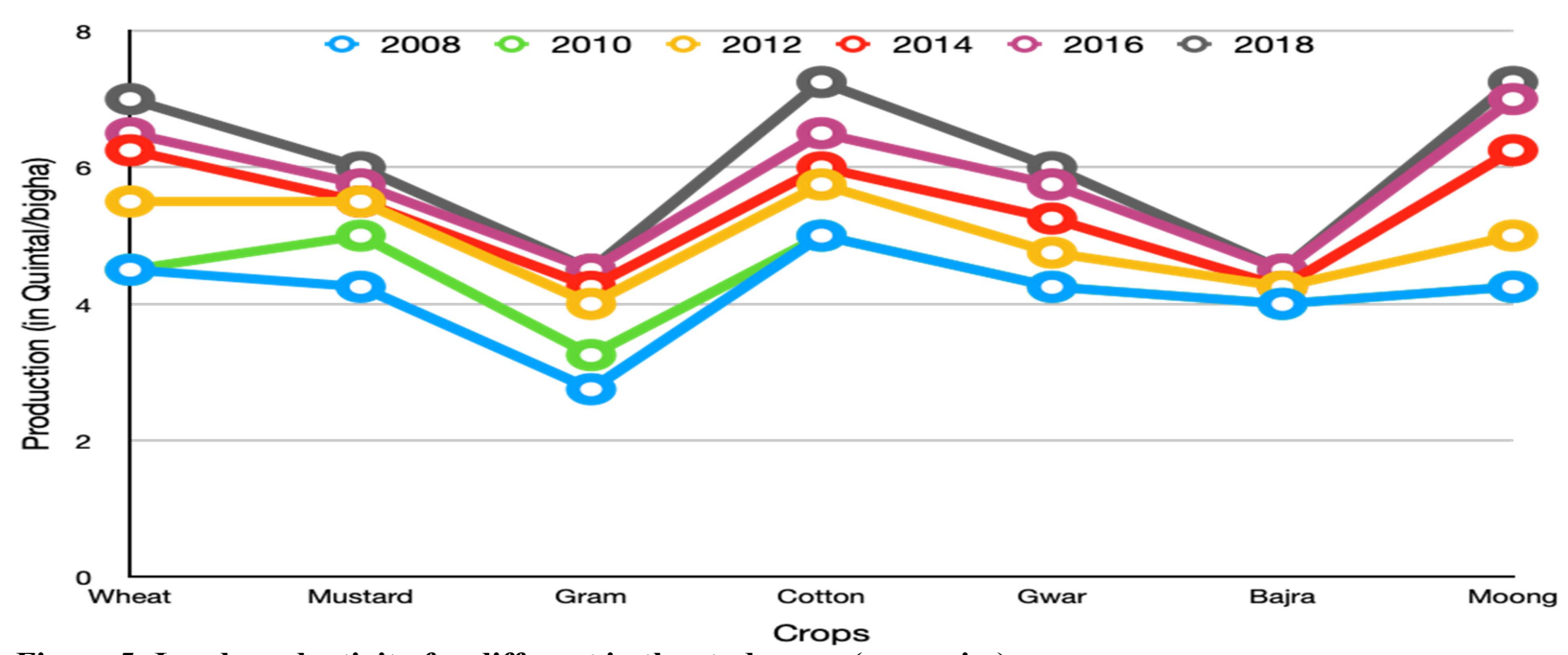

Figure 5: Land productivity for different in the study area (year-wise)

More precisely, it is unveiled that in the initial years of the SCIP command area development, the Bajra was the dominant crop. Afterwards, the cropping pattern changed from Bajra, Gwar and Taramira to Wheat, Cotton, and Groundnut. As Wheat and Cotton are high-value cash crops (high market price crops) and water-intensive crops (irrigated crops) (Aldaya et al., 2010), substantial water availability in the region modified farmers' preference for grown crops. This change in cropping pattern also pushed the economic development in the region.Over time, A sound decline in the rain-fed crops (Bajra, Gwar, Taramira) and an increase in the irrigated crops (Wheat, Cotton, Groundnut) unambiguous indicated the positive impact of the SCIP on the cropping pattern. In addition, some other mixed (irrigated/rain-fed) farming also remained identical, such as Mustard and Moong; however, Taramira has omitted from the study area.

\section{Modification in land productivity}

The land productivity was calculated for the various crops grown in the study area from the collected data that revealed a significant consecutive rise in all the crops. The land productivity observed for Wheat, 4.5 quintal/bigha in 2008, further increased up to 7.0 quintal/bigha until the year 2018 . Similarly, land productivity for Mustard in 2008 was 4.25 quintal/bigha and increased up to 6.0 quintal/bigha in 2018; for Gram in 2008 was 2.75 quintal/bigha and increased up to 4.50 quintal/bigha in 2018; for Cotton in 2008 was 5.0 quintal/bigha and increased up to 7.25 quintal/bigha in 2018; for Gwar in 2008 was 4.25 quintal/bigha and increased up to 6.0 quintal/bigha in 2018; for Bajra in 2008 was 4.0 quintal/bigha and increased up to 4.50 quintal/bigha in 2018; for Moong in 2008 was 4.25 quintal/bigha and increased up to 7.25 quintal/bigha in 2018 (Table-3, Figure-5 \& 6). Land productivity is a function of irrigation efforts (Clemmens \& Molden, 2007; Boubaker et al., 2016). The present study affirms improved irrigation by SCIP command area development has raised the land productivity of the seven major crops of the study area. The observations strongly support that the inception of the SCIP and the development of its command area have improved the study area's land productivity. Further, this enhanced productivity is also encouraging economic development and societal upliftment.

\section{Conclusion}

The introduction of the Sidhmukh Canal Irrigation Project (SCIP) converted the barren and rain-fed agricultural land to canal irrigated fertile land and caused a systematic frameshifting in the cropping pattern of the study area. Furthermore, agriculture productivity also increased from 2-4 quintal/bigha to 6-7 quintal/bigha. Indeed, this addition was caused by improved irrigation and command area development. Thus, SCIP has justified its proposed objectives and benefiting the region for an agricultural prosperity. 


\section{Bainda and Malhotra}

\section{References}

Aldaya, M. M., Muñoz, G. and Hoekstra, A. Y. 2010. Water footprint of cotton, wheat and rice production in Central Asia. UNESCO-IHE.

Boubaker Dhehibi, B., Ali El-Shahat, A. A. I. and Hassan, A. A. 2016. Impacts of irrigation on agricultural productivity in Egypt. Annals of Arid Zone, 55(3\&4): 67-78.

Clemmens, A. J. and Molden, D. J. 2007. Water uses and productivity of irrigation systems. Irrigation Science, 25: 247-261. https://doi.org/10.1007/s00271-0070067-y

Ghosh, Gargi. 2011. Challenges to Agriculture in Rajasthan. Political Economy Journal of India, 20.3-4: 101.

GOR. 2019. Rajasthan Agriculture Statistics, Department of Agriculture, Government of Rajasthan.

GOR. 2019. Rajasthan Economic Review, Directorate of Economics and Statistics, Government of Rajasthan.

Hakkim, V. A., Joseph, E. A., Gokul, A. A. and Mufeedha, K. 2016. Precision farming: the future of Indian agriculture, Journal of Applied Biology and Biotechnology, [Online](November), 068-072.
Kala, N. 2017. Learning, adaptation, and climate uncertainty: Evidence from Indian agriculture. MIT Centre for Energy and Environmental Policy Research Working Paper, 23.

Kavdia, P. S. 1993. Development of Irrigation and its Utilisation. Irrigation and Power Journal, 50(4): 181-192.

Kumar, M. and Rai, A. 1993. Surface Water Resources and its Utilisation for Irrigation in Rajasthan. Irrigation and Power Journal, 50(4): 143-146.

Mueller, L., Schindler, U., Mirschel, W. et al. (2010). Assessing the productivity function of soils. A review. Agronomy Sustaiable Develeopment, 30: 601-614.

Rockström, J., Jennie, B. and Patrick, F. 2003. Water productivity in rain-fed agriculture: challenges and opportunities for smallholder farmers in drought-prone tropical agroecosystems. Water productivity in agriculture: Limits and opportunities for improvement 85199.669: 8.

Schrevel, A. 1997. Sidhmukh and Nohar Irrigation Project (ALA 91/35). Farmers' Participation in Chak Development (A Mission Report). 